\title{
ASIAN POWERS IN AFRICA:
WIN, WIN, WIN, WIN?
Brittany Morreale
}

YI JINPING DESCRIBED the Belt $\chi_{\text {and Road Initiative (BRI) as the }}$ project of the century' at the inaugural Belt and Road Forum for International Cooperation held in Beijing in May, promising that it would herald a new type of international relations featuring win-win cooperation'. ${ }^{12}$ But along with cooperation, there is competition - and when it comes to the Belt and Road's Indo-Pacific maritime route and its designs on Africa, Japanese and Indian leaders have expressed strong reservations about Chinese security and economic architectures.

China's interest in Africa dates back to the 1950s, when Communist Party Chairman Mao Zedong sought to inspire revolutionary movements across the Third World. Mao's successors largely abandoned their ideolog- ical emphasis on China's engagement with Africa, instead framing their quest in economic and diplomatic terms. By 2009, African countries including Tanzania, Nigeria, and Sudan received nearly forty-six per cent of the PRC's officially reported development budget (more than any other region); that year, China also surpassed the US to become the continent's most important trading partner..$^{13}$ Today, African resources, including raw materials such as crude oil, metals, and timber are vital to the realisation of the 'China Dream'. At the same time, Chinesefinanced roads, railroads, and ports have helped advance Africa's integration into the global economy. However, China's ongoing economic realignment raises questions about the viability of high-risk Chinese investment in Africa 
and the implications of mounting debt in nations such as Kenya and Nigeria.

With nearly one trillion US dollars in BRI-related infrastructure and development investments announced at the Forum comes the potential for billions more for Africa. This builds upon Xi Jinping's announcement of a US $\$ 60$ billion commitment to African development financing at the 2015 Forum on China-Africa Cooperation in Johannesburg. The Belt and Road blueprint already includes large-scale infrastructure projects such as the Addis Ababa-Djibouti railway, the Sudanese oil pipeline, and Djibouti military facility. The Chinese-financed US\$3.2 billion Nairobi-Mombasa railroad, commissioned in May 2017, is Kenya's largest infrastructure project since independence in 1963. Accordingly, Kenyahas been designated as an African hub in BRI maritime route proposals by the Chinese state media. Beijing has signed agreements with several African nations, building upon a concept of coastal maritime hubs along the Eastern seaboard with infrastructure networks spanning across the continent.

But China is not the only Asian player in Africa. In 2015, Indian Prime Minister Narendra Modi promised
US $\$ 10$ billion in concessional loans and US\$600 million in grants over the next five years. Last year, Japanese Prime Minister Shinzo Abe promised US $\$ 30$ billion in public and private infrastructure investment over the next three years on top of the US $\$ 32$ billion already pledged from 2013 to 2018, putting Japanese development financing and aid to African countries on par with Chinese investment.

In May 2017, Japan and India announced their own bold vision for regional connectivity, the AsiaAfrica Growth Corridor. A 2016 joint statement issued by the Japanese and Indian prime ministers stressed that 'connectivity between Asia and Africa, through realizing a free and open Indo-Pacific region, is vital to achieving prosperity of the entire region'. This corridor envisions Indo-Pacific maritime sea lanes with a central focus on Africa, integrating African economies with the powerhouses of the AsiaPacific through policy vehicles crafted by India and Japan. With the US and Europe turning inward and focussing on domestic economic issues at the expense of foreign development agendas, China, Japan, and India are jockeying for position as leaders in environmental protection, economic development, 


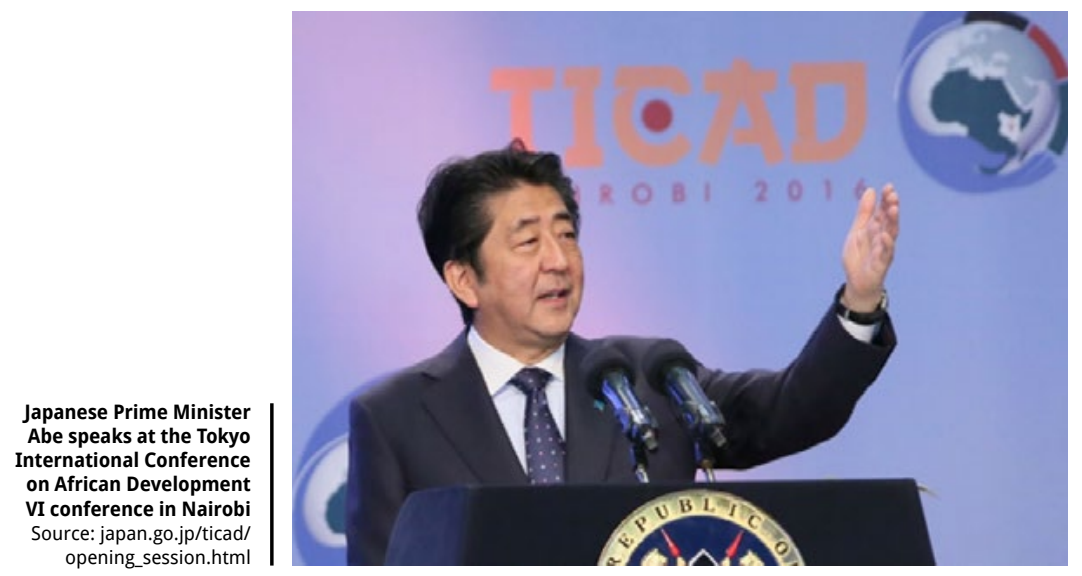

and global market integration in Africa and beyond.

In 1993, Japan hosted the first Tokyo International Conference on African Development (TICAD). Like China, Japan offered African states an alternative to Western development models, basing its programs on its time-tested paradigm of self-help and consultation, with an emphasis on infrastructure building. The sixth TICAD was convened in 2016, and, for the first time, in Africa itself. Its framework of African ownership and empowerment and the use of 'forum diplomacy' appears to have inspired China's Forum on China-Africa Cooperation in 2000, as well as the Korea-Africa Forum and the India-Africa Forum Summit, which convened for the first time in
2006 and 2008 respectively. Following Japan's example, forum diplomacy leverages a multi-lateral platform as the focal point to project social, political, and economic power. Through this increasingly potent mechanism, China, Japan, India, and, on a smaller scale, Korea have advanced Asian-African policy alignment and economic cooperation. It was Tokyo's concept of an 'Arc of Freedom and Prosperity', first formulated by then foreign minister Taro Aso in 2006, that has evolved into the Asia-Africa Growth Corridor.

Throughout the twentieth century, India cultivated strong soft-power ties with African countries through the anti-colonial struggle, its leadership of the Non-Alignment Movement, and shared migration. Yet India, like 


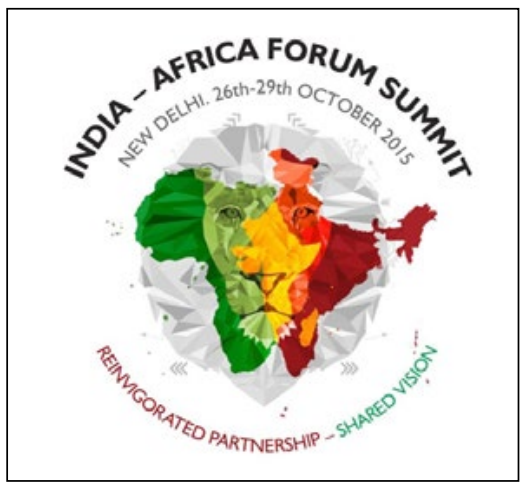

Emblem of the India-Africa Forum Summit 2015 Source: mea.gov.in

China, was for a long time itself a recipient of economic aid, which limited its economic engagement with African countries. With India's transition from beneficiary to donor in the 2000s, Africa became a testing ground for New Delhi's foreign aid and development policies. In Africa, India has focussed on technical capacity-building by providing training for defence and UN peacekeeping personnel. In addition, New Delhi granted tens of thousands of scholarships to students from countries across Africa, including Kenya, Nigeria, and South Sudan, gaining footholds in nations also courted by China with scholarships and aid. India's Pan-Africa e-Network project is the continent's most extensive information and communications technology project. It aims to connect all fifty-three member states of the African Union with India through a satellite and fibre-optic network. The e-network has provided ingenious solutions, such as telecasted education, and digital disease diagnosis, to improve delivery of education and medical services to many of Africa's remote communities.

\section{Why Africa?}

There are a number of economic and diplomatic reasons for growing interest of Asian countries in Africa. First, Africa's relatively unexploited domestic markets and abundant natural resources offer the industrialised and emerging powers of Asia both inputs and outlets for continued growth. Second, in the UN General Assembly, China, India, and Japan see the African voting bloc as a critical support for achieving diplomatic goals. The bloc can help to insulate the PRC from criticism while advancing its agendas within international institutions. It is also capable of assisting Japan and India in their quest for permanent representation on the UN Security Council. Finally, Africa offers a 'neutral' testing ground where Japan, India, and China can deploy new development and 
security initiatives without significant interference or repercussions from the US and Europe, or regional rivals.

For example, all three Asian nations have deployed naval forces to the Indian Ocean region to support anti-piracy missions and secure sea lanes along the Horn of Africa. Japan and China have also each established an overseas base in Djibouti as a hub for maritime security and peacekeeping efforts. Africa's insulation from the tensions and flashpoints of the Asian region, such as the East and South China Seas, allows Japan, China, and India to experiment with conflict mediation and diplomacy. For example, following the outbreak of civil war in South Sudan in 2013, Japan deployed its Self Defence Forces abroad for the first time ever. China worked with an African regional body to mediate a ceasefire in South Sudan, testing a reinterpretation of noninterference.

Africa's future is increasingly bound up with the grand visions of Asian powers. As Kenyan President
Uhuru Kenyatta said at TICAD VI on 27 and 28 August 2016:

As a continent straddling the Indian Ocean, we have access to the investment and markets of Asia ... we have come so far from the time when solutions were prescribed without the input of Africa's people. $^{14}$

The recent windfall of Asian investment offers African states alternatives to traditional Western models of development and their accompanying demands. Unlike Western programs, these Asian investment projects emphasise mutually beneficial partnerships and self-reliance without the conditionality of traditional aid. In these 'partnerships', more responsibility shifts to African nations to negotiate the terms of economic cooperation with China, India, and Japan. Ultimately, competition between Asian powers and more choice in development partners and pathways benefits African states. 
This text is taken from China Story Yearbook 2017: Prosperity, edited by Jane Golley and Linda Jaivin, published 2018 by ANU Press, The Australian National University, Canberra, Australia.

doi.org/10.22459/CSY.04.2018.03B 